\title{
The Method of Exercise Play Has an Impact on Under Passing Ability Volleyball Players
}

\author{
Eri Barlian ${ }^{1 *}$ and Doni Jaswanto Anpolu ${ }^{2}$ \\ ${ }^{1,2}$ Dep. of Coaching, Faculty of Sport Science, Universitas Negeri Padang, Padang, Indonesia \\ *Corresponding author. Email: e.barlian@fik.unp.ac.id
}

\begin{abstract}
The problem in this study is the provision of a variety of exercises in increasing the ability to pass under the volleyball. This study aims to determine the effect of playing training methods on the passing ability under the volleyball players of Painan1 High School. This research is a quasi-experiment. Sampling using a purposive sampling technique amounting to 12 people. This research was conducted for 6 weeks (18 meetings), in 1 week the training was held 3 times. The research instrument used was the repeated volley test. Data analysis techniques using the t-test formula with a significant level $\mathrm{a}=0,05$. Based on data analysis in this study usethe Test $t$-test. The results of data processing in this study were obtained tcount $(8,84)>$ table $(2,201)$ and there was an increase in the results of the ability between the initial test and the final test. This means that the application of play training methods has an influence on the ability to pass under the volleyball players of SMA N 1 Painan, the southern coastal district.
\end{abstract}

Keywords: Method Play Capability Passing Down volleyball

\section{INTRODUCTION}

The Indonesian nation which is a developing country today is striving to build and improve capabilities in all fields for the advancement and welfare of the nation, the builders basically demand that people are physically and mentally healthy. Sport is wrong one event for me Reach physical fitness to obtain maximum results, implementing exercise should be done systematically and continuously. This is in line with one of the national sports goals in RI Law Number 3 of 2005 concerning the National Sports System. Chapter 2 article 4 which reads:

National sports aim to choose and improve health and fitness, achievement, quality of life, instill moral values and noble morals, sportsmanship, discipline, strengthen and foster national unity, strengthen national resilience, and enhance national dignity, dignity.

Based on the sound of the article above, one of the goals of national sports is to increase the achievement of both regional, national and international. This emphasizes even more in article 27 paragraph 1 that reads: "Coaching and development of sports achievements are carried out and directed to achieve sports achievements at the Regional, National and International levels."

Based on the background of the problem, identification, and limitation of the problem above, it can be made a problem formulation, namely "Does the method of playing practice affect the ability to pass under the volleyball players of SMA N 1 Painan.

According to Ahmadi (2007) "Techniques in volleyball games consist of service, passing over, blocks, and smashes." Passing is a technique in volleyball game whose aim is to pass the ball to one place or to one's own friends in a team, bottom passing is the main element to defend the team from the opponent's attack, the ball is too hard and difficult to play with top passing, then taken with under passing (Erianti, 2011).

The game ball volleyball to know sometechniques basic amongothers passing on, passing below, serve, block and smash. All the techniques arein need and important to at mastered by students as a basisfor the exercise participantsmust first recognize passing. According toBeutehstahl(2007 ) " To be able to play ball volley with a well, a person must understand and really be able to master the technique of ball control with good".

According to Beutehstahl (2007). " Passingunder the technical basis of the earliesttaught to students or players beginners. Passing on a technique of playing a ball that is done by a player ball volleyballwith the goalto drivethe ball that played to somewhereor toa friendly teamfor in playon the field itself ".

Mahendra. (2003) explained that the objective of physical education learning must include blocks, and smashes. Mastery of basic techniques is very important in order to play volleyball properly 
The learning method is an important aspect of the learning process. The health teacher needs to learn and understand various learning methods that are appropriate to be applied to children according to their level. Sudjana (2013) states, the teaching method is the method used by the teacher in establishing relationships with students during teaching.

Much is gained from playing activities, namely one of which is able to develop physical aspects because students will continue to move freely without coercion. But playing, besides having an important function for personal development, also has social and emotional functions. Through play, children experience various emotional experiences; happy; sad; passionate; disappointed; proud; mar ah; etc. In addition, play activities are closely related to children's cognitive development. (Tedjasaputra, 2001).

Widijoto (2006) states that the play method is a way of teaching using games, the aim being that students understand the benefits of certain game techniques by introducing certain game situations to children.

Play is an opportunity for children to express their emotions naturally, "play" (play) is a term that is used freely so that the main meaning may be lost in the most place according to Mahendra (2008)

Slameto (2003) describes the game as "a medium that enhances cognitive development. The game allows children to practice the competitions and skills needed in a relaxed and fun way. "

According to Tedjasaputra MS (2001), play is a matter relating to activities that give the effect of satisfaction in the process. Whether we realize it or not, this activity will run if it is carried out without a burden. This is because although this activity is physical in nature but its impact is very influential on physical matters.

From some experts, it can be concluded that the relationship of sports with play, sports, and physical education involves forms of movement, and both can be crushed appropriately in an educational context if used for educational purposes. Playing can be relaxing and entertaining so that it can be used as a tool to practice the basic technical skills of a sport because students will exercise exercises with joy so that it will eliminate the effects of fatigue.

In this study one method of teaching is implemented in the learning of basic under passing techniques. The method used is the method of play, which is to learningstudents with the various forms of the game that led to the movement of passing down, so that students are expected to be more actively engaged, more daring and more trust themselves in learning. This is also based on Manalu's (2017) research that uses the play method, but is applied to learning to run fast.

Training through the method of play is an activity that involves several people, the occurrence of high social relations and fun, and encouraging. The practice of mini volleyball technique using the method of playing will be impressed that the participation of each student in playing activities will show different levels of skill.

Passing is one of the most important techniques in a game, especially in volleyball games. Passing also has certain techniques in order to produce effective and good passing. Passing is also divided into 2 types, namely passing down and passing up. These two passes are often compared to other techniques because passing is the main key in the volleyball game. If a player does not master the passing technique to the maximum in a match it will have difficulty in a team. According to NurilAhmadi (2007)

according to Erianti (2004) passing down is the main element to defend the team from the opponent's attack, besides to defend it also plays a very important role in building the pattern of attacks on the opposing team. Passing down can be done with one hand or with both hands whose use is appropriate to the situation to be achieved

According to Bacthiar (1999) " passing in a volleyball game is a technique of playing a ball by a player" passing is also referred to as bait, the bait in question is a dish given to a teammate to be hit by attacking the opponent's plot. Passing is also the first step to developing attack patterns.

Passing down must be done as well as possible. Bachtiar (1999: 103) argues "the implementation of good passing is directed in accordance with the correct coordination of movements, directed in accordance with the wishes of the collection so that it helps to provide a bait that is appropriate and appropriate. According to Syafruddin (2012: 54) states that " physical condition is an element or basic ability that must be possessed by every player to achieve a sporting achievement". Therefore, each training program that is carried out is the development of conditions components related to the general and specific. This is supported by the opinion of Blume (2004: 22) which states that, "the technical abilities and tactics of a volleyball player is determined by the components of strength, endurance, speed, flexibility, and coordination.

Athlete motivation, interests, talents infrastructure, physical condition, practice passing under individuals, exercises passing under paired-eye coordination drills and exercises hand play regular method with the predetermined position can also 
increase the ability of passing down. Researchers see passing down as very useful in playing volleyball.

Success in receiving services by using underpass is a basic capital to start a good attack. Because an attack is usually determined by good and directed under passing so that the feeder can make the right bait and in accordance with the wishes of the smasher. This is in accordance with what was stated by Erianti (2004: 115) " passingdown is the main element to defend the team from the opponent's attack, diampin to maintain also very important role to support the opponent's team attack patterns.

Passing is divided into 2, namely passing down and passing up. Passing under a key element to maintain a team of the opponent's attack, while passing on a technique that determines the success of the team to build up a good attack.

\section{RESEARCH METHODS}

This type of research is classified as quasiexperimental (Quasi experimental), this study to see whether there is influence between two or more variables quantitatively. The research design used is " Two Groups Pretest-Posttest Design", namely research designs that are pre-tested before being treated and posttest after being treated thus can be known to be more accurate, because it can be compared to held before being treated (Sugiyono, 2007).

Barlian (2016), population is the totality of all values that exist on certain characteristics of a number of objects that want to be studied its characteristics, population is a generalization area consisting of objects / subjects that have certain qualities and characteristics set by researchers to be studied. All players consist of 24 players, 12 male players and 12 female players.

sample is part of the number and The characteristics possessed by the population, then sampling technique applied by purposive sampling, the technique of determining the sample is based on consideration of the goals set by the researcher, Barlian (2016). The sample used was only male students who numbered 12 people.

Place Field research was conducted in SMA N 1 Painan regencysouth pesisir.

The implementation of the test is, Testy with the ball in the hand facing the target wall. After there was a signal "YES" from the ball officer, the wall was attached to the target, and carried out passing for 30 seconds. Testy performed 3 treatments, the value of each trial was the number of valid reflections. In accordance with the rules and the target area if the ball on the ball line is considered legitimate. If the ball cannot be mastered by the teste, the teste may take the tramp ball and start again to finish the test until time runs out. Next is the recording of results, recording results must be made in a way. Every ball that goes to the target area passed and done from behind the boundary line gets a value of one. One teste's score is chosen the best number of scores from 3 treatments.

Research instruments The data collection tool in this study was the reatead volleyballs test. Internal Validity To gain confidence about the design of this study conducted control through validity. validitycomes from an English dictionary which means truth. A measurement instrument or research instrument is said to be valid or true, if an instrument is said to have high validity if the instrument measures what we should measure internal and external validity. Control of internal validity in the study design is done so that it can be believed that the results obtained from this research are the influence of the treatment given to the experimental group. The aspects that are controlled for internal validity are: Aspects of the effect of the initial test. Controlled by keeping the men's volleyball atlet of Painan N 1 High School not aware that at the end of the trial the same test will be carried out, so that the male volleyball players of Painan N 1 High School do not prepare themselves specifically for the final test, as long as they are still being treated. Aspects of the influence of the instrument, controlled by not making changes to the instruments used, the initial tests and final tests still use the same instrument. The moral aspect is controlled by keeping a tight presence in the treatment and training period and guiding the movements carried out so that the implementation is as it should be. External validity Controller external validity so that research results are generalized to the study population. The controller can be done by means of (1) taking samples according to the characteristics established in this study (2) sample selection is done by tottal sampling technique.

The data collection technique Tools and equipment walls are flat and smooth with a high target of 3 meters and a width of 2 meters, Volleyball 5 pieces, Stop watch, Duct Tape, Meter, Blank research, Stationery, Whistles .

Data Analysis Techniques Data were taken from two measurements, namely the pre-test before treatment and post-test after treatment was given. This aims to obtain research data that will be processed to test the hypothesis. Before testing the hypothesis first testing the analysis requirements regarding the normal distribution. In this case the Lilliefors (Sudjana) normality test is performed. After testing the analysis requirements are met, hypothesis testing is done. Hypotheses are tested by means of the different test mean analysis ( $t$ test) of related samples. 
Initial Test Results (Pre Test) Lower Passing Ability Description of the data from the initial test (pre test) under passing ability can be seen in the following table :

\begin{tabular}{|c|c|c|c|}
\hline No & Interval & Absolute Frequency $(\mathrm{Fa})$ & Relative frequency (Fr) \\
\hline 1 & $11-14$ & 4 & 33.33 \\
\hline 2 & $15-18$ & 5 & 41.67 \\
\hline 3 & $19-22$ & 2 & 16.67 \\
\hline 4 & $23-26$ & 1 & 8.33 \\
\hline 5 & $27-30$ & 0 & 0 \\
\hline & amount & 12 & $100 \%$ \\
\hline
\end{tabular}

\section{RESULTS AND DISCUSSION}

Based on the tables distribution frequencies above 12-person sample, $4(33.33 \%)$ included in the interval 11-14, 5 (41.67\%) belongs to the interval 15-18, $2(16.67 \%)$ belongs to the interval $19-22,1$ person
$(8.33 \%)$ was in the $23-26$ interval, and 0 people $(0 \%)$ were in the 27-30 interval.

The results of the final test (post test) under passing ability Decryption of data the results of the final test (post test) under passing ability can be seen in the following table ;

\begin{tabular}{|c|c|c|c|}
\hline No & Interval & Absolute Frequency (Fa) & Relative frequency (Fr) \\
\hline 1 & $12-15$ & 3 & 25 \\
\hline 2 & $16-19$ & 2 & 16.67 \\
\hline 3 & $20-23$ & 4 & 33.33 \\
\hline 4 & $24-27$ & 3 & 25 \\
\hline 5 & $28-31$ & 0 & 0 \\
\hline & amount & 12 & $100 \%$ \\
\hline
\end{tabular}

Based on the frequency distribution table above from 12 people sampled, 3 people $(25 \%)$ included in the $12-15$ interval, 2 people $(16.67 \%)$ included in the $16-19$ interval, 4 people $(33.33 \%)$ included in the 20 interval 23,3 people $(25 \%)$ were included in the interval $24-27$, 0 people $(0 \%)$ were included in the $28-31$ interval .

\section{Discussion}

From the hypothesis which states that there is a significant effect between playing training methods on increasing the passing ability under the volleyball. This is seen from the average increase in the ability to pass under 30 seconds through the initial test (pre test) and the final test (post test). Increased average rat a capability of passing down for 30 seconds with exercise method playing exercise, the initial test 16.50 increased to 19.33 .

Furthermore, the results of the analysis which state that there is a significant influence between playing training methods on increasing the ability to pass under the volleyball players of Painan $\mathrm{N} 1$ High School is evidenced by the results of the analysis that there is $t_{\text {count }}=8.84$. Greater than $t$ table $=2,201$ that training using the play training method can be applied to improve the passing ability under the volleyball.
After being observed at the time of the study, the authors saw the practice of playing a training method is very necessary to improve the ability to pass under. Coupled with long training exercises that are programmed, systematic, directed and continuous, it will increase the ability to pass under. But, for players who are often not present in the implementation of the training program, the increase in the ability to pass under the lower will be lower than the players who always follow the training program exercise method.

In addition to exercise, physical condition, mental, nutrition, infrastructure also affects an increase in the ability of under passing, condition physical note to increase the capability of passing down therefore very is required as training plan put forward Suharto HP (1981) "a volleyball player having a peak physical condition can be interpreted as having the ability to play volleyball efficiently without experiencing exhaustion ". Mental abstinence is also needed to improve the ability of under passing. The purpose of mental preparation is to provide as much knowledge as possible about bottom passing. The tension that may be the case should be avoided. As stated by Blume Guntur (2004: 18) "information to provide knowledge to players must be given as objectively as possible and as early as possible is the mental attitude". In addition, good nutritional 
intake can also affect the ability to pass under the volleyball. Before doing the training the player must have energy and energy to be ready to do the level of training. If the nutritional intake and energy come out balanced, this can help improve the player to train with enthusiasm. the most important thing to consider is facilities and infrastructure, without the means and infrastructure that are adequate Athletes/players cannot do training, and of course, can affect the increase in under passing. Tools and infrastructure as supporting exercises for example, without the volleyball, the field, etc., passing training the bottom cannot be carried out effectively and efficiently.

\section{CONCLUSIONS AND SUGGESTIONS}

Based on the results of research and hypothesis testing, it can be concluded that there is a significant influence of the play training method on the passing ability of the volleyball players in SMA N 1 Painan. Studying with passing techniques with the actual playing practice method can improve the results of passing tests under the volleyball players of Painan $\mathrm{N} 1$ High School. With the value of $\mathrm{t}$ count 8,84 while $\mathrm{t}$ table amounted to 2.201 with significant level $\mathrm{a}=0.05$ and $\mathrm{n}=12$, then $\mathrm{t}>\mathrm{t}$ table $(8.84>2.201)$. With its influence can be seen from the average test where the average pre-test ability under 16.50 passing while the average post-test increased to 19.33 (increased). This means that there is an increase in the ability to pass under the use of play training methods. Suggestions For coaches or instructors who have clubs, the form of play training method is a form of training method that enhances the ability of under passing so that it can help to get good under passing skills. To the players to be able to carry out training programs that have been prepared by the coach in an effort to improve his performance. It is recommended for writers who are interested in further researching to pay attention to other variables can also affect the ability to pass under. For writers who are interested in further research, it is recommended to be able to increase the number of samples and study other forms of exercise. To the reader in order to be a guide for writing a thesis that will come with the same variable.

\section{REFERENCES}

[1] Astuti, Yuni. 2017. Effect of Drill Method and Playing Method on Mini Volleyball Playing Skills (Experimental Study in 14 Public Elementary School Students in KampungJambak, Koto Tangah District, Padang City). mi teacher education journal (2017) vol 4 (1): 01-16
[2] Bachtiar (1997). Basic knowledge of volleyball games. Padang: Padang State University FIK

[3] Barlian Eri. (2016). Qualitative \& quantitative research methodology. Padang: Sukabina Press

[4] Erianti (2004). Bolavoli Teaching Book. Padang. FIK UNP

[5] Fetrianto, Faizal, Sulistyorini. 2016. Efforts to Improve Passing Skills under Oil Bolav Using the Playing Method for Students of Class VI SdNegeriPolowijen 02 Blimbing District Malang. Journal of Sports Coaching, Vol. 1 No. 1 October 2016

[6] Hambali, Sumbara.2016. Pembelajaran Passing Down Method Using Play the game Volleyball Elementary School Students Class V. Education Journal of Sport, Vol. 5, No. 1, June 2016.

[7] Hambali, Sumbara, and Sutiswo.2019. Playing Methods Influence terhadap Results Belajar Passing Down Volleyball di Elementary School. Journal of Educational Perspectives - Vol. 33 No.1 April 2019

[8] Hanafi, Ridwan.2017. Effect of Method of Playing Handball And Throw Catch Ball terhadap Effectiveness of Learning Passing Over volleyball p No Class Xii TphpSmk Son Wilis District of Spring Regency Tulungagung. Sports Learning Journal Volume 3 Number 2 Year 2017

[9] Herlina, June. 2019. P engaruh Method of Exercise Playing terhadap ability Passing Down volleyball. Journal of Patriot.Unp 2019

[10] Hidayat Syarif.2018. The Influence of Playing Method on the Improvement of Lower Passing in Volleyball Game SmkNegeri 1 Subang Excurricular Students. Fkip Scientific Journal, Subang University Vol. 4 No. 01 February 2018 Issn (P) 2461-3961 (E) 2580-6335

[11] Maulana, mercy. 2017. The Influence of the Play Approach to the Increasing of Lower Passion for Extracurricular Participants in Godean 1 Junior High School. Scientific Journal (FIK UNY) Number 012017 pp 1-10

[12] Samsudin S. 2016. Effect of Learning Method Drill, Play, and agility terhadap ability Passing $d$ natural Ball Game Volleyball. Journal of Sports Volume 4 - Number 2, September 2016, (207220)

[13] Sudarajat, Destiawan.2015. The Effect of Playing Method on Increasing Passing Ability Under the Male Volleyball Extracurricular Participants of 
SMA Negeri 6 Purworejo. Scientific Journal (FikUny). Number 062015

[14] Sugiyono (2010). Educational Research Methods. Bandung: CV. Alfabeta.

[15] Syafruddin ( 2007). Basics of Sports Coaching.

Padang: DIP State University Padang

Project
[16] RI Law No. 3. (2005) and RI government regulations (2007). National Sports System. Bandung: Cintra Umbara 